\title{
Study on antihyperglycemic effect of bromocriptine in dexamethasone induced hyperglycemic wistar rats
}

\author{
Rekha M. B.*, Basavaraj Bhandare, Satyanarayana V., Hemamalini M. B.
}

Department of Pharmacology, RRMCH, Bangalore, Karnataka, India

\author{
Received: 20 April 2021 \\ Revised: 11 May 2021 \\ Accepted: 12 May 2021 \\ *Correspondence: \\ Dr. Rekha M. B., \\ Email: dr.rekhamb@gmail.com
}

Copyright: (C) the author(s), publisher and licensee Medip Academy. This is an open-access article distributed under the terms of the Creative Commons Attribution Non-Commercial License, which permits unrestricted non-commercial use, distribution, and reproduction in any medium, provided the original work is properly cited.

\begin{abstract}
Background: Diabetes mellitus is a chronic metabolic disorder that develops due to insulin deficiency or insulin resistance. Recent animal and human studies have reported bromocriptine to be effective in the management of type 2 diabetes mellitus. The present study was done to evaluate the antihyperglycemic effect of bromocriptine in dexamethasone induced hyperglycemic rats.

Methods: Male wistar rats were used and divided into 5 groups. Dexamethosone was used to induce hyperglycemia in group B-E. Group A was the untreated control group, group B was the standard control group, group C was the oral 10 $\mathrm{mg} / \mathrm{kg}$ of bromocriptine dissolved in $0.9 \%$ normal saline, group D was the oral $20 \mathrm{mg} / \mathrm{kg}$ metformin dissolved in $0.9 \%$ normal saline, group E was the oral $10 \mathrm{mg} / \mathrm{kg}$ bromocriptine+20 mg/kg metformin dissolved in $0.9 \%$ normal saline. Fasting blood glucose, post prandial blood glucose and body weight was estimated on day 1, 15, 30.

Results: It was seen that dexamethasone induced hyperglycemia and increase in body weight in male wistar rats, which were significantly controlled by oral bromocriptine and bromocriptine with metformin combination.

Conclusions: Results obtained from this study showed that bromocriptine can be a promising drug with novel mechanism to treat type 2 diabetes mellitus.
\end{abstract}

Keywords: Bromocriptine, Wistar rats, Diabetes mellitus, Metformin

\section{INTRODUCTION}

Diabetes mellitus is characterized by chronic hyperglycemia with disturbances of carbohydrate, fat and protein metabolism resulting from defects in insulin secretion, action or both. A changing lifestyle in developing countries like India has enormously increased the burden of chronic diseases like diabetes mellitus. The global burden of diabetes mellitus is estimated to be 425 million in 2017. It is among the top ten causes of death in adults and was estimated to have caused 4 million deaths globally in 2017. ${ }^{1}$ India leads the world with largest number of diabetic subjects earning the dubious distinction of being termed as diabetes capital of world. The number of people with diabetes mellitus in India is 73 million. $^{2}$

Diabetes mellitus is associated with various complications like ischemic heart diseases, retinopathy, nephropathy, neuropathy if blood sugars are not adequately controlled. Management of diabetes mellitus includes lifestyle modifications, pharmacotherapy and nutritional therapy. Type 1 diabetes is treated with insulin. For type 2 diabetes mellitus various antidiabetic drugs like sulfonylureas, biguanides and alpha glucosidase inhibitors are used.

Despite having so many antidiabetic drugs in the market, the search for new antidiabetic drug continues. This is 
because the treatment of type 2 diabetes mellitus has always remained challenging with only about half or less of the patients achieving desired glycemic control and weight reduction. Thus, there is a need for new therapies in managing type 2 diabetes mellitus.

Recent animal and human studies have reported bromocriptine to be effective in the management of type 2 diabetes mellitus. Bromocriptine was recently approved by the United State food and drug administration in 2009 for the clinical management of type 2 diabetes mellitus. Bromocriptine is believed to achieve good glyceamic control in type 2 diabetes mellitus subjects based on the observation that bromocriptine administered within 2 hours of awakening resulted in augmentation of low hypothalamic dopamine levels and inhibit excessive sympathetic tone within central nervous system. ${ }^{3}$ It also causes reduction in postprandial plasma glucose levels due to enhanced suppression of hepatic glucose production without corresponding augmentation of insulin secretion or enhance insulin sensitivity in the skeletal muscles. ${ }^{4}$ Bromocriptine is well known to induce weight loss by centrally inhibiting the activity of hunger center in the hypothalamus. ${ }^{5}$ Thus it would help in weight reduction in diabetic patients who are usually obese.

In view of this need, the present study was designed to evaluate the therapeutic potential of bromocriptine in combination with metformin in type 2 diabetes mellitus using dexamethasone induced hyperglycemic rats as an animal model.

\section{Objective}

The objective of the study was to study the antihyperglycemic effect of bromocriptine in dexamethasone induced hyperglycemic rats.

\section{METHODS}

Healthy male wistar rats weighing between 150-225 grams were taken for the study. The animals were kept in clean and dry cages, with 12:12 hours light-dark cycle at room temperature and humidity. They were acclimatized for 14 days to the available housing condition and were fed with diet consisting of soaked black gram (kala channa) and water ad libitum. Arrangements were made to ensure regular cleaning of cages and disposal of excreta and urine. The cages were floored with a layer of saw dust for absorption of urine of rats. The whole experiment was conducted in accordance with ethical guidelines approved by institutional animal ethics committee (IAEC) of Raja Rajeswari medical college. This study was done at Raja Rajeswari medical college and hospital, Bengaluru between October 2018 to February 2019.

\section{Drugs used}

The drugs used in the study were dexamethasone sodium phosphate, bromocriptine mesylate and metformin.

\section{Chemical and reagent kits}

The chemicals and reagent kits used were distilled water, dettol and sterilized cotton, normal saline, glucometer, glucometer strips, disposable syringe $5 \mathrm{ml}$, animal feeding needle (gavage tube), sterilized needle and surgical blades.

\section{Dexamethasone induced hyperglycemia}

Animals were divided into five groups, each consisting of six rats. Single, daily oral treatments of the experimental rats with drugs were described. Group A was $10 \mathrm{ml} / \mathrm{kg}$ of $0.9 \%$ normal saline P.O.+1 $\mathrm{ml} / \mathrm{kg}$ of $0.9 \%$ normal saline, S.C.=untreated control group; group B was $10 \mathrm{ml} / \mathrm{kg}$ of $0.9 \%$ norml saline P.O=standard control group; group C was oral $10 \mathrm{mg} / \mathrm{kg}$ of bromocriptine dissolved in $0.9 \%$ normal saline; group D was oral $20 \mathrm{mg} / \mathrm{kg}$ metformin dissolved in $0.9 \%$ normal saline; group $\mathrm{E}$ was oral 10 $\mathrm{mg} / \mathrm{kg}$ bromocriptine $+20 \mathrm{mg} / \mathrm{kg}$ metformin dissolved in $0.9 \%$ normal saline.

One hour later all rats in the treatment groups B-E were given S.C. injection of dexamethasone $10 \mathrm{mg} / \mathrm{kg}$. The treatments were conducted for 30 days.

\section{Measurement of body weight}

Body weights of treated rats were measured on the 1st, 15 th and 30th day of the experiment with a weighing balance.

\section{Estimation of fasting blood glucose}

After overnight fasting FBG levels of all rats were determined on day 1,15 and 30. Post prandial blood glucose was estimated after $1 \frac{1 / 2}{2}$ hours of feed on day 1,15 and 30 . Blood samples were collected from the tail of rat.

\section{Statistical analysis}

All the data were analyzed using descriptive and inferential statistics using mean, SD and t test. Results were considered significant if $\mathrm{p}<0.05$.

\section{RESULTS}

\section{Effect on body weight}

As shown in the table 1 there is significant increase in the body weight in standard control group on day 30 .

There is significant decrease in body weight in group C-E on day 15 and day 30 . 
Table 1: Effect of bromocriptine, metformin and bromocriptine-metformin combination on body weight on day 1 , 15 and 30.

\begin{tabular}{|c|c|c|c|c|c|c|c|c|}
\hline Group & $\begin{array}{l}\text { Treat- } \\
\text { ment }\end{array}$ & 1st day & $\begin{array}{l}\text { 15th } \\
\text { day }\end{array}$ & 30th day & $\begin{array}{l}\text { t test } \\
(\mathrm{df}=10) \\
\text { 1st and } \\
\text { 30th day }\end{array}$ & $P$ value & $\begin{array}{l}\text { t test } \\
(\mathrm{df}=10) \\
\text { 15th and } \\
\text { 30th day }\end{array}$ & P value \\
\hline Untreated control & 1 & $\begin{array}{l}175.83 \pm \\
8.78\end{array}$ & $\begin{array}{l}175.83 \pm \\
7.94\end{array}$ & $\begin{array}{l}183.83 \pm \\
7.33\end{array}$ & 2.641 & 0.024 & 1.813 & 0.099 \\
\hline Standard control & 2 & $\begin{array}{l}172.17 \pm \\
6.21\end{array}$ & $\begin{array}{l}219.17 \pm \\
18.43\end{array}$ & $\begin{array}{l}236.367 \pm \\
13.66\end{array}$ & 10.529 & $<0.0001$ & 1.869 & 0.091 \\
\hline Bromocriptine & 3 & $\begin{array}{l}163.83 \pm \\
3.82\end{array}$ & $\begin{array}{l}160.83 \pm \\
2.40\end{array}$ & $\begin{array}{l}150.17 \pm \\
2.64\end{array}$ & -7.206 & $<0.0001$ & -7.319 & $<0.0001$ \\
\hline Metformin & 4 & $\begin{array}{l}160.17 \pm \\
6.24\end{array}$ & $\begin{array}{l}153.33 \pm \\
4.89\end{array}$ & $\begin{array}{l}131.17 \pm \\
3.06\end{array}$ & -10.221 & $<0.0001$ & -9.410 & $<0.0001$ \\
\hline $\begin{array}{l}\text { Bromocriptine+ } \\
\text { metformin }\end{array}$ & 5 & $\begin{array}{l}169.67 \pm \\
7.55\end{array}$ & $\begin{array}{l}143.33 \pm \\
6.02\end{array}$ & $\begin{array}{l}105.17 \pm \\
7.52\end{array}$ & -14.826 & $<0.0001$ & -10.975 & $<0.0001$ \\
\hline
\end{tabular}

Table 2: Effect of bromocriptine, metformin and bromocriptine-metformin combination on fasting blood glucose (FBS) on day 1, 15 and 30.

\begin{tabular}{|c|c|c|c|c|c|c|c|c|}
\hline Group & $\begin{array}{l}\text { Treat- } \\
\text { ment }\end{array}$ & 1st day & $\begin{array}{l}\text { 15th } \\
\text { day }\end{array}$ & 30th day & $\begin{array}{l}\mathrm{t} \text { test } \\
(\mathrm{df}=10) \\
\text { 1st and } \\
\text { 30th day }\end{array}$ & P value & $\begin{array}{l}\text { t test } \\
(\mathbf{d f}=10) \\
\text { 15th and } \\
\text { 30th day }\end{array}$ & P value \\
\hline Untreated control & 1 & $\begin{array}{l}65.83 \pm \\
3.06\end{array}$ & $\begin{array}{l}67.33 \pm \\
2.16\end{array}$ & $\begin{array}{l}68.67 \pm \\
2.88\end{array}$ & 1.655 & 0.128 & 0.912 & 0.383 \\
\hline Standard control & 2 & $\begin{array}{l}64 \pm \\
2.83\end{array}$ & $\begin{array}{l}106.5 \pm \\
9.09\end{array}$ & $\begin{array}{l}147.8 \pm \\
10.61\end{array}$ & 18.700 & $<0.0001$ & 7.246 & $<0.0001$ \\
\hline Bromocriptine & 3 & $\begin{array}{l}65.33 \pm \\
3.08\end{array}$ & $\begin{array}{l}59.17 \pm \\
2.14\end{array}$ & $\begin{array}{l}58.1 \pm \\
1.72\end{array}$ & -5.020 & 0.0005 & -0.955 & 0.362 \\
\hline Metformin & 4 & $\begin{array}{l}66.83 \pm \\
1.47\end{array}$ & $\begin{array}{l}54.17 \pm \\
2.48\end{array}$ & $\begin{array}{l}52.50 \pm \\
1.64\end{array}$ & -15.938 & $<0.0001$ & -1.376 & 0.198 \\
\hline $\begin{array}{l}\text { Bromocriptine+ } \\
\text { metformin }\end{array}$ & 5 & $\begin{array}{l}66.17 \pm \\
2.79\end{array}$ & $\begin{array}{l}57.67 \pm \\
2.25\end{array}$ & $\begin{array}{l}43.50 \pm \\
3.27\end{array}$ & -12.918 & $<0.0001$ & -8.744 & $<0.0001$ \\
\hline
\end{tabular}

Table 3: Effect of bromocriptine, metformin and bromocriptine-metformin combination on post prandial blood glucose on day 1, 15 and 30 .

\begin{tabular}{|c|c|c|c|c|c|c|c|c|}
\hline Group & $\begin{array}{l}\text { Treat- } \\
\text { ment }\end{array}$ & 1st day & 15th day & 30th day & $\begin{array}{l}\text { t test } \\
(\mathbf{d f}=\mathbf{1 0}) \\
\text { 1st and } \\
\text { 30th day }\end{array}$ & P value & $\begin{array}{l}\text { t test } \\
(d f=10) \\
15 \text { th and } \\
\text { 30th day }\end{array}$ & P value \\
\hline Untreated control & 1 & $\begin{array}{l}131.83 \pm \\
5.04\end{array}$ & $\begin{array}{l}129.17 \pm \\
5.00\end{array}$ & $\begin{array}{l}133.16 \pm \\
2.22\end{array}$ & 0.592 & 0.5673 & 1.787 & 0.1043 \\
\hline Standard control & 2 & $\begin{array}{l}135.16 \pm \\
4.99\end{array}$ & $\begin{array}{l}168.33 \pm \\
5.31\end{array}$ & $\begin{array}{l}177 \pm \\
5.01\end{array}$ & 14.494 & $<0.0001$ & 2.909 & 0.0156 \\
\hline Bromocriptine & 3 & $135 \pm 4$ & $\begin{array}{l}130.16 \pm \\
1.47\end{array}$ & $\begin{array}{l}132.83 \pm \\
4.70\end{array}$ & -0.861 & 0.4093 & 1.328 & 0.2137 \\
\hline Metformin & 4 & $\begin{array}{l}137.83 \pm \\
1.72\end{array}$ & $\begin{array}{l}127.33 \pm \\
3.72\end{array}$ & $\begin{array}{l}124 \pm \\
3.22\end{array}$ & -9.28 & $<0.0001$ & -1.658 & 0.1283 \\
\hline $\begin{array}{l}\text { Bromocriptine+ } \\
\text { metformin }\end{array}$ & 5 & $\begin{array}{l}135.5 \pm \\
3.93\end{array}$ & $\begin{array}{l}119.16 \pm \\
1.16\end{array}$ & $\begin{array}{l}109.66 \pm \\
2.73\end{array}$ & -13.227 & $<0.0001$ & -7.845 & $<0.0001$ \\
\hline
\end{tabular}

\section{Effect on FBS}

Table 2 given below shows that there is significant increase in FBS in standard control group on day 15 and day 30.
There is significant decrease in FBS in group C, D on day 30. Whereas significant decrease in FBS is seen in group $\mathrm{E}$ on day 15 and day 30 . 


\section{Effect on post prandial blood glucose}

As shown in Table 3 it is seen that there is significant increase in PPBS in standard control group on day 30.

The significant decrease in PPBS is seen in group D on day 30 and significant decrease in PPBS is seen in group E on day 15 and day 30 .

\section{Overall comparison of treated groups with standard control}

Comparison with standard control group B, group C-E shows significant decrease in body weight, FBS and PPBS as shown in Table 4.

Table 4: Comparison of treated groups with standard control.

\begin{tabular}{|c|c|c|c|c|c|c|c|c|c|c|c|c|}
\hline \multirow{3}{*}{ Treatments } & \multicolumn{12}{|c|}{ 3oth day } \\
\hline & \multicolumn{4}{|c|}{ Body weight } & \multicolumn{4}{|l|}{ FBS } & \multicolumn{4}{|l|}{ PPBS } \\
\hline & $\begin{array}{l}\text { Mean } \pm \\
\text { SD }\end{array}$ & $\begin{array}{l}\text { Differ } \\
\text { ence }\end{array}$ & $\begin{array}{l}t \text { test } \\
(\mathbf{d f}=10)\end{array}$ & $\begin{array}{l}P \\
\text { value }\end{array}$ & $\begin{array}{l}\text { Mea } \pm \\
\text { SD }\end{array}$ & $\begin{array}{l}\text { Differ } \\
\text { ence }\end{array}$ & $\begin{array}{l}t \text { test } \\
(\mathbf{d f}=10)\end{array}$ & $\begin{array}{l}P \\
\text { value }\end{array}$ & $\begin{array}{l}\text { Mea } \pm \\
\text { SD }\end{array}$ & $\begin{array}{l}\text { Diff- } \\
\text { erence }\end{array}$ & $\begin{array}{l}t \text { test } \\
(\mathbf{d f}=10)\end{array}$ & P value \\
\hline $\begin{array}{l}\text { Standard } \\
\text { control }\end{array}$ & \multicolumn{4}{|c|}{$236.367 \pm 13.66$} & \multicolumn{4}{|c|}{$147.83 \pm 10.61$} & \multicolumn{4}{|c|}{$177 \pm 5.01$} \\
\hline $\begin{array}{l}\text { Standard } \\
\text { control+ } \\
\text { bromocriptine }\end{array}$ & $\begin{array}{l}150.17 \\
\pm 2.64\end{array}$ & 86.5 & -15.22 & $\begin{array}{l}<0.00 \\
01\end{array}$ & $\begin{array}{l}58.1 \pm \\
1.72\end{array}$ & 89.73 & -20.44 & $\begin{array}{l}<0.00 \\
01\end{array}$ & $\begin{array}{l}132.8 \pm \\
4.70\end{array}$ & 44.17 & -15.75 & $<0.0001$ \\
\hline $\begin{array}{l}\text { Standard } \\
\text { control+ } \\
\text { metformin }\end{array}$ & $\begin{array}{l}131.17 \\
\pm 3.06\end{array}$ & 105.5 & -18.46 & $\begin{array}{l}<0.00 \\
01\end{array}$ & $\begin{array}{l}52.50 \pm \\
1.64\end{array}$ & 95.33 & -21.75 & $\begin{array}{l}<0.00 \\
01\end{array}$ & $\begin{array}{l}124 \pm \\
3.22\end{array}$ & 53 & -21.79 & $<0.0001$ \\
\hline $\begin{array}{l}\text { Standard } \\
\text { control+ } \\
\text { bromocriptine } \\
\text { +metformin }\end{array}$ & $\begin{array}{l}105.17 \\
\pm 7.52\end{array}$ & 131.5 & -20.65 & $\begin{array}{l}<0.00 \\
01\end{array}$ & $\begin{array}{l}43.50 \pm 3 \\
27\end{array}$ & 104.33 & -23.01 & $\begin{array}{l}<0.00 \\
01\end{array}$ & $\begin{array}{l}109.6 \pm \\
2.73\end{array}$ & 67.34 & -28.91 & $<0.0001$ \\
\hline
\end{tabular}

This means bromocriptine alone and bromocriptine with metformin combination are effective in decreasing body weight, FBS, PPBS in dexamethasone induced hyperglycemic rats.

\section{DISCUSSION}

Bromocriptine is a D-2 agonist. This centrally acting antidiabetic agent has a new mechanism of action and it reduces blood glucose, body weight and possibly cardiovascular events. Bromocriptine modulates central glucose and energy metabolism pathways. ${ }^{6,7}$ A quick release formulation of bromocriptine administered within two hours of awakening is believed to stimulate low hypothalamic dopamine levels and inhibit excessive sympathetic tone within central nervous system, resulting in decrease in postprandial glucose levels due to enhanced suppression of hepatic glucose production. ${ }^{8}$

In the study, hyperglycemia and weight gain were induced by dexamethasone which is a potent diabetogenic agent. Dexamethasone induced weight gain and hyperglycemia were controlled by pre-treatment with bromocriptine alone and bromocriptine in combination with metformin. However, the effect was more pronounced with bromocriptine and metformin combination than bromocriptine alone. This observation was also seen in previous study by Powers. ${ }^{9}$

In the treatment of type 2 diabetes mellitus apart from controlling blood sugars, weight reduction is also a task. Many antidiabetic drugs like sulfonylureas cause weight gain. But bromocriptine is seen to decrease body weight which makes bromocriptine a more desirable antidiabetic drug. In a previous study by Cincotta et al similar observations were noted. ${ }^{10}$

\section{Limitations}

The limitation of this study was that this study was done on animals so more clinical studies to be done with bromocriptine with other drug combinations to reconfirm its efficacy and safety.

\section{CONCLUSION}

Results obtained from this study showed that bromocriptine can be a promising drug with novel mechanism to treat type 2 diabetes mellitus.

\section{Funding: No funding sources}

Conflict of interest: None declared

Ethical approval: The study was approved by the Institutional Ethics Committee

\section{REFERENCES}

1. International Diabetes Federation. IDF Diabetes Atlas, 8th ed. Brussels, Belgium: International Diabetes Federation; 2017

2. Cho NH, Shaw JE, Karuranga S, Huang Y, Fernandes JDR, Ohlrogge AW. IDF Diabetes Atlas: global estimates of diabetes prevalence for 2017 and projection for 2045. Diabetes Res Clin Pract. 2018:138:271-81. 
3. Shivaprasad C, Kalra S. Bromocriptine in type 2 diabetes mellitus. Ind $\mathrm{J}$ Endocr Metabol. 2011:15(1):17-24.

4. Maharajan R, Gupta K, Kapoor V. A systematic account of pathogenesis, diagnosis and pharmacotherapy of metabolic syndrome. Things we need to know. Int J Pharmacol. 2010:6(4):338-45.

5. Norris SL, Zhang X, Avanell A, Gregg E, Schmid CH, Kim C, et al. Efficacy of pharmacotherapy for weight loss in adults with type-2 diabetes mellitus: a metaanalysis. Arch Intern Med. 2004:164(13):1395-404.

6. Kerry JL, Timpe EM, Petkewicz KA. Bromocriptine mesylate for glycemic management in type-2 diabetes mellitus. Ann Pharmacother. 2010;44(11):1777-85.

7. Via MA, Chandra H, Araki T, Potenza MV, Skamagas M. Bromocriptine approved as the first medication to target dopamine activity to improve glycemic control in patients with type-2 diabetes. Diabetes Metab Syndr Obes. 2010;3:43-8.
8. Defronzo RA. Bromocriptine: A sympatholytic D2 dopamine agonist for the treatment of type 2 diabetes. Diabet Care. 2011;34(4):789-94.

9. Powers AC, D'Alessio D. Endocrine pancreas and pharmacotherapy of diabetes mellitus and hypoglycemia. Goodman and Gilman's the pharmacological basis of therapeutics. New York: Brunton Medical; 2018: 1237-73.

10. Cincotta AH, Meier AH. Bromocriptine reduces body weight and improves glucose tolerance in obese subjects. Diabetes Care. 1996;19(6):667-70.

Cite this article as: Rekha MB, Bhandare B, Satyanarayana V, Hemamalini MB. Study on antihyperglycemic effect of bromocriptine in dexamethasone induced hyperglycemic wistar rats. Int J Basic Clin Pharmacol 2021;10:669-703. 